E

51

.1393

IDIAN NOTES

no. 13

, MONOGRAPHS

NMAIREF EdIted By F. W. Hodge

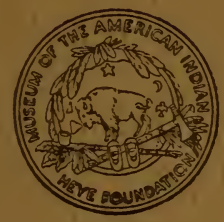

A SERIES OF PUBLICA. TIONS RELATING TO THE AMERICAN ABORIGINES

HUNTING CHARMS OF THE MONTAGNAIS AND THE MISTASSINI

BY

FRANK G. SPECK AND

GEORGE G, HEYE

NEW YORK

MUSEUM OF THE AMERICAN INIDIAN HEYE FOUNDATION

1921 
This series of INDIAN No'tes and MoNographs is devoted primarily to the publication of the results of studies by members of the staff of the Museum of the American Indian, Heye Foundation, and is uniform with HisPanic Notes and Monographs, published by the Hispanic Society of America, with which organization this Museum is in cordial coöperation.

Only the first ten volumes of INDIAN Notes AND MonOGRAPHS are numbered. The unnumbered parts may readily be determined by consulting the List of Publications issued as one of the series. 


\section{INDIAN NOTES AND MONOGRAPHS}

Edited By F. W. Hodge

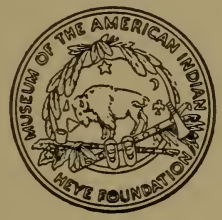

A SERIES OF PUBLICA. TIONS RELATING TO THE AMERICAN ABORIGINES

\section{HUNTING CHARMS OF THE MONTAGNAIS AND THE \\ MISTASSINI}

BY

FRANK G. SPECK

AND

GEORGE G. HEYE

NEW YORK

MUSEUM OF THE AMERICAN INDIAN

HEYE FOUNDATION 



\title{
HUNTING CHARMS OF THE MONTAGNAIS AND THE MISTASSINI
}

\author{
BY \\ FRANK G. SPECK \\ AND \\ GEORGE G. HEYE
}





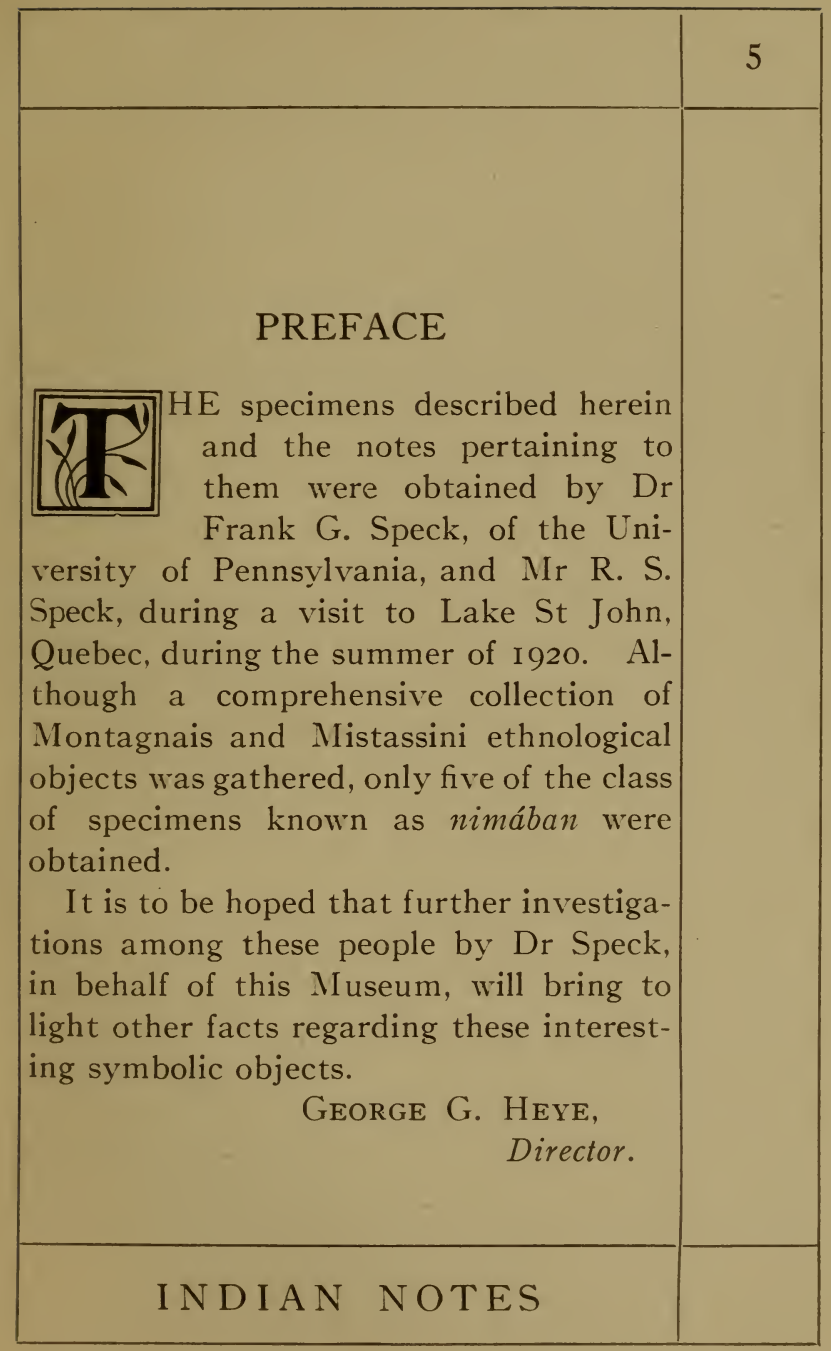





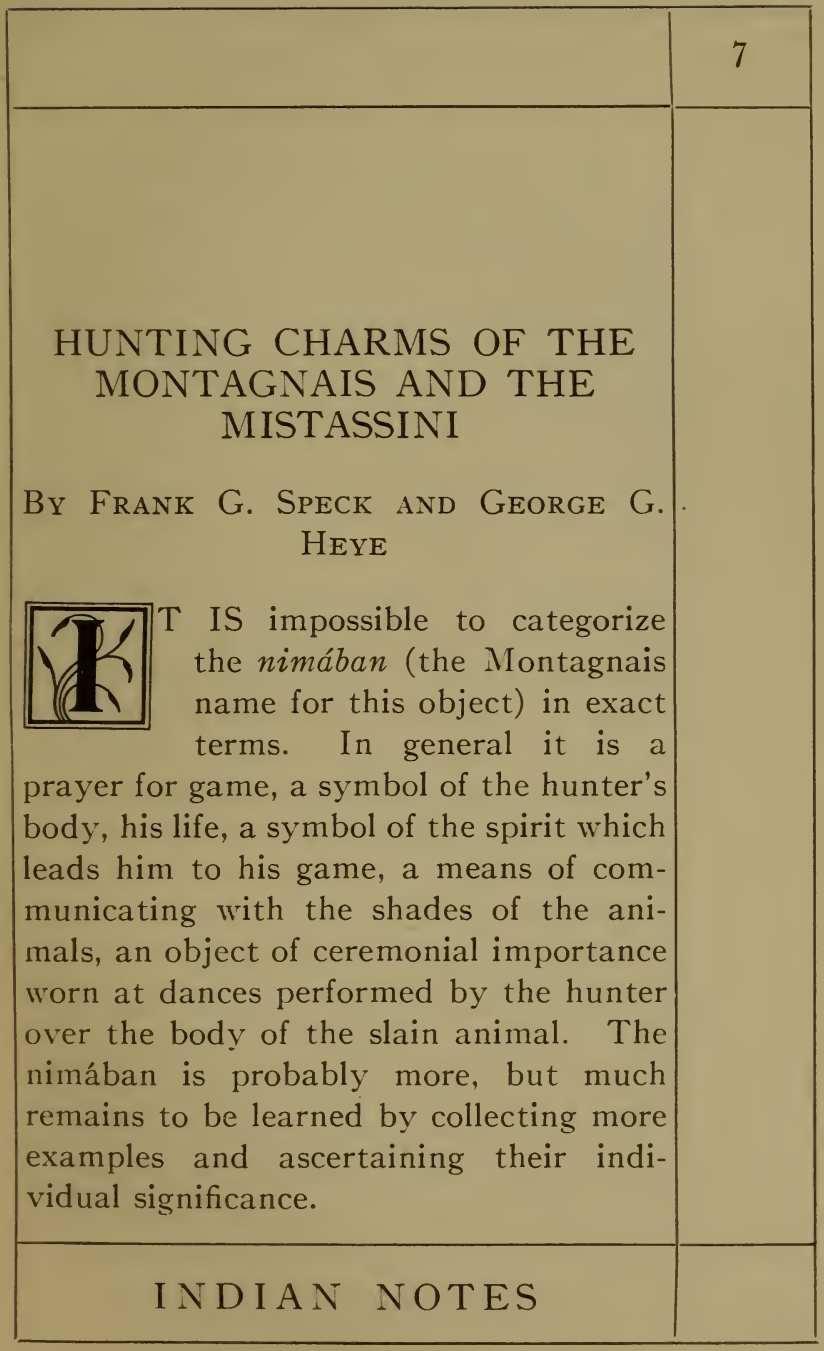




\begin{tabular}{|c|c|}
\hline 8 & HUNTING CHARMS \\
\hline & $\begin{array}{l}\text { The term nimában seems to signify } \\
\text { "dance-cord," from nimi-, "dance," and } \\
\text { the common Algonkian stem -aban, denot- } \\
\text { ing "string," "length of something plia- } \\
\text { ble," which occurs in cognitive forms } \\
\text { throughout eastern dialects: compare, for } \\
\text { example, Penobscot - } A b i \text { (wo } b_{A} \text { 'bi, "wam- } \\
\text { pum;" agama'bi, "snowshoe string;" } \\
\text { maksAnA'bi, "moccasin string;" wu- } \\
\text { skwA'bi, "carrying strap"), and Malecite } \\
-a^{\prime} p^{\prime}, \text { Micmac - } a^{\prime} b e \text {. Most of these tribes } \\
\text { know the term nimában as a pack-strap, } \\
\text { but its symbolic aspect is not emphasized } \\
\text { as among the northern St Lawrence divi- } \\
\text { sions of the group, so far as is now known. } \\
\text { Spread over an extremely wide range } \\
\text { of country, the various bands of the sub- } \\
\text { Arctic, semi-maritime hunters known in } \\
\text { literature as the Montagnais ("moun- } \\
\text { taineers"), exhibit considerable variation } \\
\text { in dialect and custom. From Hamilton } \\
\text { river in eastern Labrador, following the } \\
\text { coast of the Gulf of St Lawrence west- } \\
\text { ward to the Saguenay, the Montagnais } \\
\text { are seafarers and forest nomads according } \\
\text { to season and fancy. There are two }\end{array}$ \\
\hline & INDIAN NOTES \\
\hline
\end{tabular}




\section{HUNTING CHARMS}

dialects on this stretch, which covers a lineal distance of 800 miles and extends about 200 miles toward the interior of Labrador to the height of land dividing the St Lawrence waters from those of the Arctic. One dialect $(a)$, spoken from Moisie river eastward, has phonetic and grammatical peculiarities akin to the Naskapi of the interior, and this is what is known as the Coast Naskapi, as the name was sanctioned years ago by Hind and other early travelers. From the Moisie westward to the Saguenay there is another-the more typical Montagnais $(b)$.

(a) Includes the Montagnais of Moisie, Mingan, Romaine, Natashquan, St Ailgustine, Eskimo river, and Hamilton inlet on the coast, and possibly Nichicun lake and Waswanipi lake in the interior.

(b) Includes the Montagnais proper of Seven islands, Godbout, Bersimis, the Papinachois of Manicouagan river and lake, Escoumains, Tadousac, Chicoutimi, and the now extinct band of Murray bay.

In the interior, at Lake St John, the

\section{AND MONOGRAPHS}




\begin{tabular}{|l|l|}
\hline 10 & \multicolumn{1}{|c|}{ H U N T I N G C H A R M S } \\
\hline $\begin{array}{l}\text { dialect is related, but grades off toward } \\
\text { the Mistassini and Cree. } \\
\text { Dialect, however, is no criterion of } \\
\text { culture; accordingly there are variations } \\
\text { in material culture, art, and mythology, } \\
\text { which make substantial differences be- } \\
\text { tween the bands, necessitating the forma- } \\
\text { tion of groups into which they may be } \\
\text { classified on the basis of both culture } \\
\text { and dialect. A long and exhaustive } \\
\text { survey and full collections will be made } \\
\text { before these groups are finally determined, } \\
\text { but at present the collections and in- } \\
\text { formation allow the Lake St John band, } \\
\text { or Pikwagami, to be classed as one; the } \\
\text { Chicoutimi, Tadousac, and Escoumains } \\
\text { bands as another; the Bersimis as an- } \\
\text { other, and so on eastward, band after } \\
\text { band, the rest awaiting more attention } \\
\text { before they can be grouped. } \\
\text { The three specimens of nimában de- } \\
\text { scribed below are classified asthe type of the } \\
\text { Pikwagami ("Flat lake," Lake St John), } \\
\text { an interior Montagnais culture interme- } \\
\text { diate between that of the coast and that } \\
\text { of the eastern Naskapi and Mistassini. }\end{array}$ \\
\hline \multicolumn{1}{|c|}{ I N D I A N N OT ES } \\
\hline
\end{tabular}




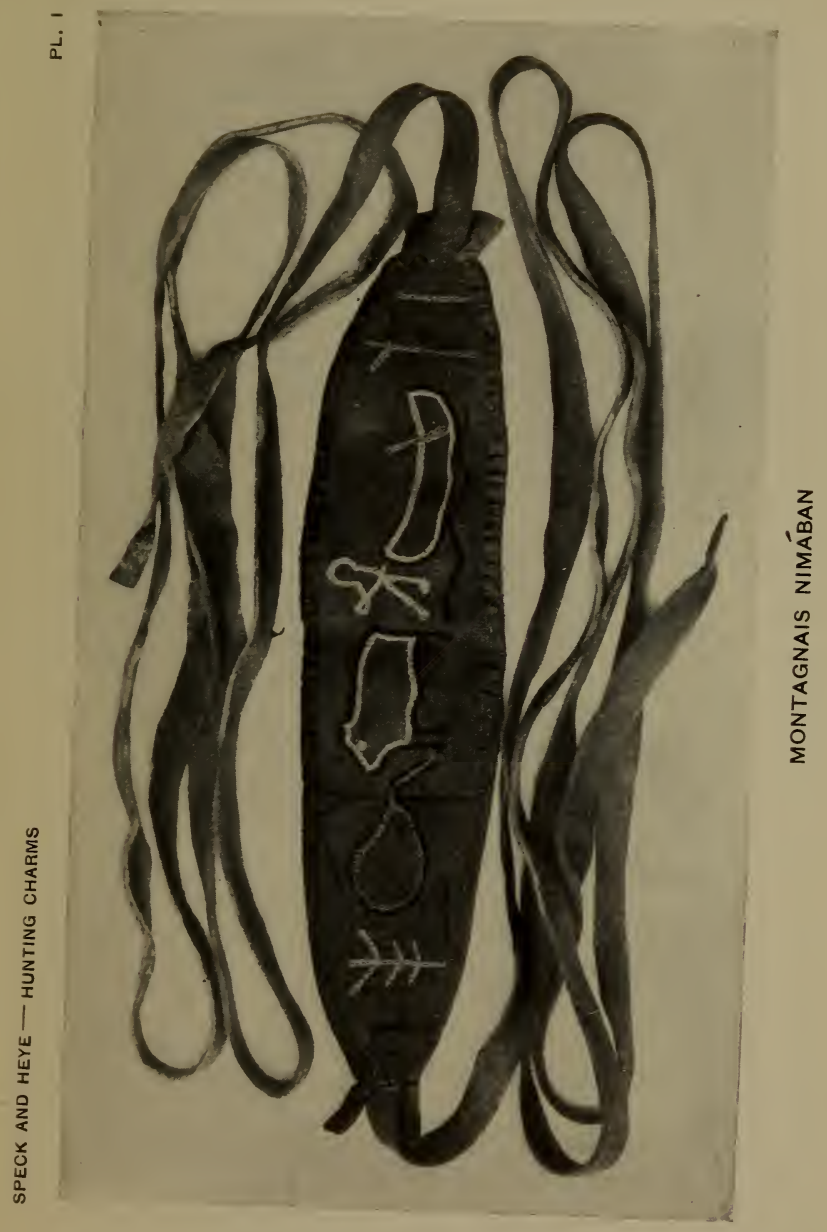





\section{H UNTING CHARMS}

The nimában shown in pl. I was used for a bear hunt, and is made of welltanned moose-skin. In form it closely imitates a pack-strap, and in fact it symbolizes one. The wide part is bound on the upper edge with a red silk ribbon, and on the lower onte with a similar ribbon of green. The scene is embroidered in red, yellow, and light-bluc sewing silks. This magical object is worn by the hunter who has had a revelation about getting game in the future. He carries this decorated strap with him on the trail, and when, true to the revelation, he gets his game, he wraps it in this strap and brings it home. The hunter keeps the strap in secret, more or less, and does not show it lest it lose its power to function as a safeguard against starvation. The figures show trees on each end, the trail and canoe, the hunter with his axe, and the bear trying to cross to a lake which has a cross trail. When the hunter finds and kills the bear, he sits down near it and smokes. After having laid the bear out on its back with crossed

\section{AND MONOGRAPHS}




\begin{tabular}{|c|c|}
\hline 12 & HUNTING CHARMS \\
\hline & $\begin{array}{l}\text { paws, he puts black tobacco in its mouth } \\
\text { and places the nimában on its breast or } \\
\text { about the neck. Sometimes before this } \\
\text { is done the hunter places the nimában } \\
\text { across his head, allowing the ends to fall } \\
\text { over his shoulders. He then dances } \\
\text { around the fallen game, at the same time } \\
\text { singing, thus expressing the hope that he } \\
\text { will have to utilize a pack-strap often in } \\
\text { bringing back game, and voicing his joy } \\
\text { at the success of his hunt. } \\
\text { The length of this specimen is } 158 \frac{1}{2} \\
\text { inches, and its extreme width at the } \\
\text { embroidered part is } 2 \frac{7}{8} \text { inches. } \\
\text { The next nimában (pl. II) is of tanned } \\
\text { moose-skin, and was made by Napani, } \\
\text { one of the oldest Montagnais hunters of } \\
\text { the Lake St John band. He said he used } \\
\text { this after returning from a hunt in which } \\
\text { he was under necessity to avert famine. } \\
\text { When the needed animal was killed, he } \\
\text { put this nimában on his forehead, dancing } \\
\text { around it once or twice singing, rejoicing } \\
\text { for luck and success, and as a recompense } \\
\text { to the spirit of the beast. This specimen, } \\
\text { also, represents a pack-strap, and as in }\end{array}$ \\
\hline & INDIAN NOTES \\
\hline
\end{tabular}




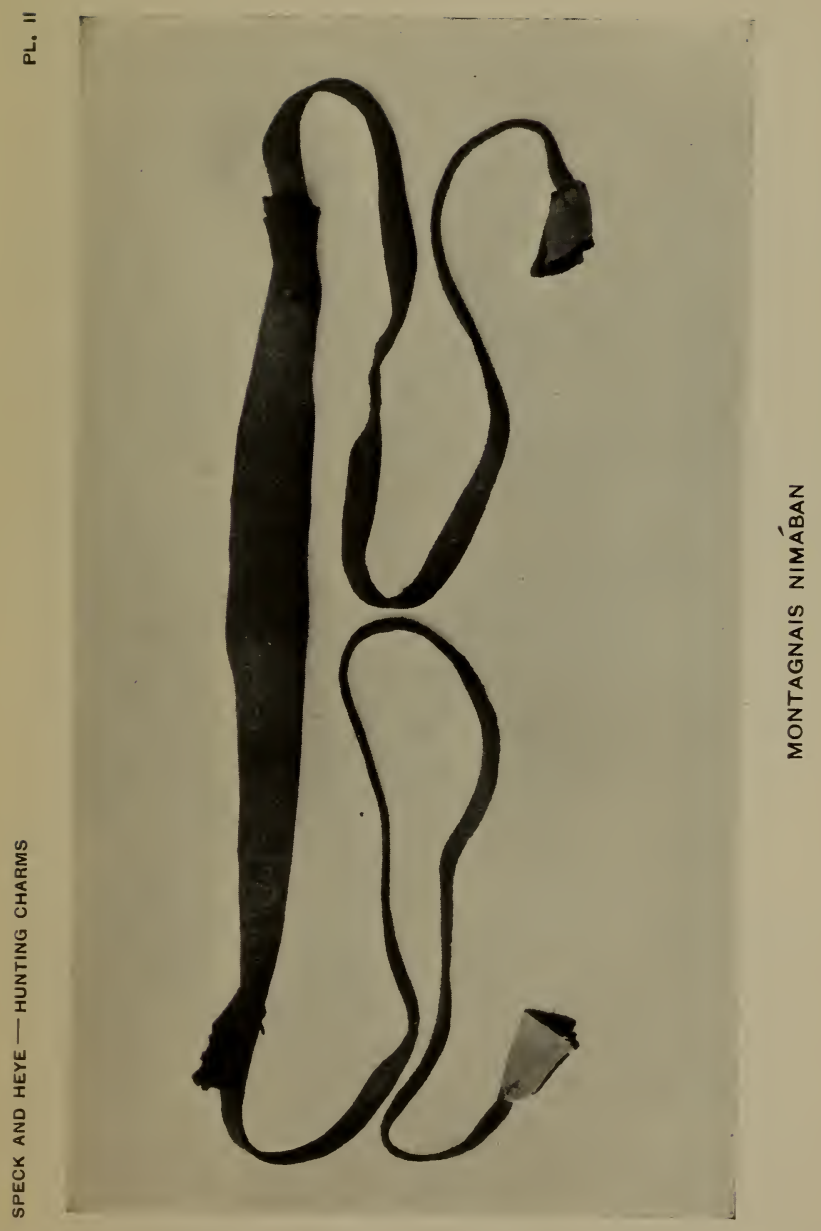





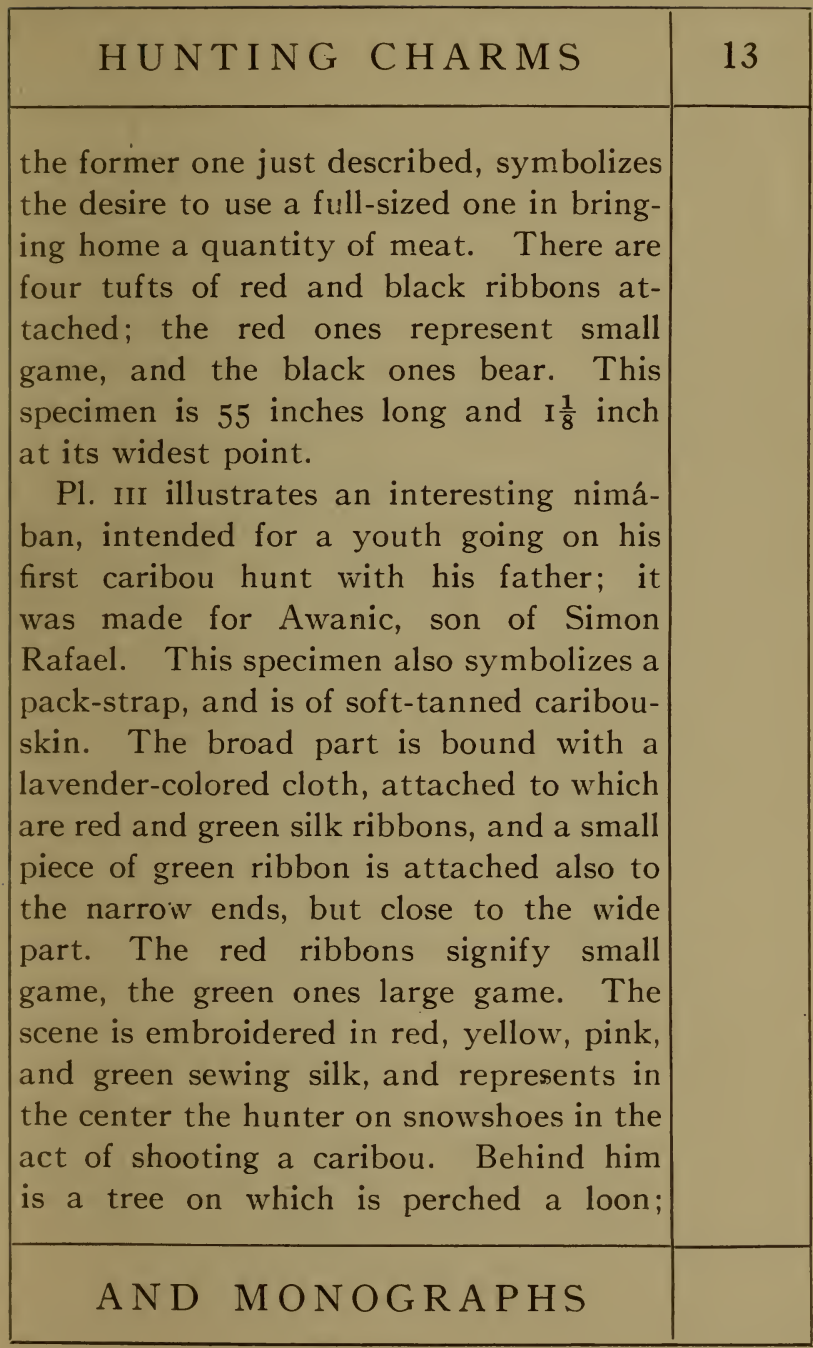




\begin{tabular}{|c|c|}
\hline 14 & HUNTING CHARMS \\
\hline & $\begin{array}{l}\text { while farther to the right is a lake con- } \\
\text { taining figures of a duck and a beaver. } \\
\text { On the left of the caribou figure is de- } \\
\text { picted another tree, and also a lake in } \\
\text { which is the figure of a gull. The curved } \\
\text { figures above and below both the "lakes" } \\
\text { represent trails. This example is } 7 \text { I } \\
\text { inches long and } 2 \frac{1}{2} \text { inches wide. } \\
\text { Lake Mistassini is about I } 75 \text { miles long } \\
\text { and half as wide; it lies approximately } 300 \\
\text { miles east of Hudson bay and } 500 \text { miles } \\
\text { north of the St Lawrence. A small Hud- } \\
\text { son's Bay Company's post is situated } \\
\text { there. For several hundred miles round } \\
\text { about the people known as Mictaci'niwi- } \\
\text { iuts ("Big Rock people"), forming a band } \\
\text { of about } 30 \text { families, live and hunt. These } \\
\text { Mistassini are very interesting; they are } \\
\text { conservative, primitive, and live under } \\
\text { great economic stress, being occasionally } \\
\text { forced to choose between cannibalism or } \\
\text { starvation. In dialect they form a group } \\
\text { with the so-called Cree of Ruperts House } \\
\text { on James bay, and to a certain extent } \\
\text { with the Indians of Waswanipi. In cul- } \\
\text { ture this same group extends eastward to }\end{array}$ \\
\hline & INDIAN NOTES \\
\hline
\end{tabular}




$$
1
$$





\section{HUNTING CHARMS}

\section{5}

and including the Naskapi. One might say of them: genus, Naskapi; species, Mistassini.

Part of this band was encountered trading at Lake St John, whence they had come some 400 to 700 miles from their hunting grounds to trade.

The nimában of the Mistassini are even more highly conventionalized than are those of the Montagnais, for they do not take the form of pack-straps, but are woven cords.

Pl. IV shows a large, white-tanned caribou-skin nimában of four strands, obtained from Mia'nckem. The nimában is Mia'nckem himself, the loop seen at the lower right-hand corner is his head, the loose end his legs. He explained the white coloring as symbolic of the caribou which he needed for his sustenance. The first ribbons symbolize: green, small game; dark-blue, bear; red wool, beaver; pink silk, lynx. In the middle the two strings of blue and white glass beads are the legs of the nimában, and symbolize caribou. The final pair of strings

\section{AND MONOGRAPHS}




\begin{tabular}{|c|c|}
\hline 16 & H UNTING CHARMS \\
\hline & $\begin{array}{l}\text { of beads are the hind-legs of the nimában, } \\
\text { and the loose string ends are the tails } \\
\text { of the nimában and symbolize "trails of } \\
\text { game." Mia'nckem said that he did } \\
\text { not display his nimában often, because } \\
\text { it weakened its power. He carried it in } \\
\text { his game-pouch, and when approaching } \\
\text { his victim often wound it about his } \\
\text { shoulders. If he took small game, he tied } \\
\text { the carcass in it and carried it suspended } \\
\text { thus over his shoulders, the head of the } \\
\text { nimában (the loop) cleated over a stick } \\
\text { piercing the nostrils of the animal, like a } \\
\text { toggle (resembling the Eskimo method } \\
\text { of dragging home seals), the "tails" of the } \\
\text { nimában tied to the animal's right hind- } \\
\text { leg. In the case of large game, he left the } \\
\text { carcass with his nimában stretched on the } \\
\text { animal's chest, its head to the animal's } \\
\text { head. Mia'nckem could sell the power } \\
\text { of his nimában, but if he gave it away } \\
\text { or lent it, it would not function. } \\
\text { The length of the nimában is propor- } \\
\text { tionate to the age of the owner, and in } \\
\text { this case is exactly I } 5 \text { feet. Young men } \\
\text { have small ones, which are replaced by }\end{array}$ \\
\hline & I NDIAN NOTES \\
\hline
\end{tabular}




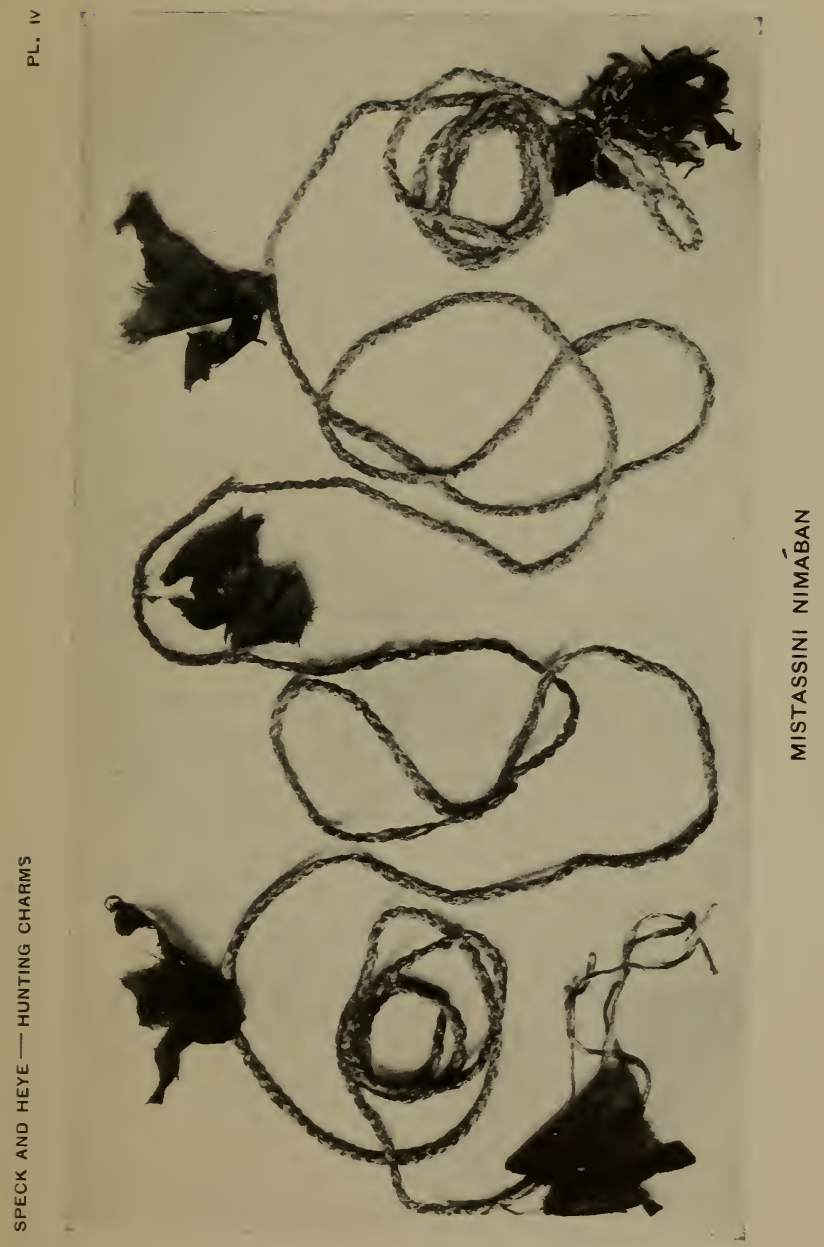





\section{H U N T I N G C H A R M S}

longer ones as they grow stronger and kill more animals.

Mia'nckem is about forty years of age. There was more to learn from him regarding this specimen, but the absence of a competent interpreter prevented the obtaining of further information.

Pl. V shows a small, smoked, caribouskin nimában belonging to Metowe'cic's son, who is about twelve years of age. His mother had made this for the boy, who was about to accompany his father on one of his first more serious hunts. The symbolism is as usual: a loop, the hunter's head; the tuft of ribbon and braid representing-blue ribbon, bear; red braid, beaver; and red silk, small game, these being the animals especially desired in this case. The boy is taught the individual symbolism by his father, and instructed in the ceremonial procedure when he has killed a beast.

The tail is four-ply, and the two song pieces tie the whole string together for carrying purposes. When a beaver is killed, the hunter pierces the septum of

\section{AND MONOGRAPHS}




\begin{tabular}{|c|c|}
\hline 18 & H UNTING CHARMS \\
\hline & $\begin{array}{l}\text { the animal's nose, inserts a stick as a } \\
\text { cleat, puts the loop or "head" of the } \\
\text { string about the cleat, and ties the two } \\
\text { longest strings of the "tail" around the } \\
\text { right hind-leg. He then smokes over the } \\
\text { beaver and carries it home, slung over his } \\
\text { shoulder on the nimában. If he should } \\
\text { get a bear, being unable to carry it alone, } \\
\text { he would smoke first, then leave his } \\
\text { nimában on the bear's chest, rolling the } \\
\text { animal on its back, the nimában doubled } \\
\text { with its head toward the bear's head. } \\
\text { IWhen an animal has been left, to enable } \\
\text { the hunter to return to camp for help, } \\
\text { it is believed no beast of prey will eat } \\
\text { the carcass while the nimában is resting } \\
\text { on its chest. Possibly the man-smell on } \\
\text { the nimában may be a safeguard. } \\
\text { Every hunter owns and carries a } \\
\text { nimában on his excursions and renews it } \\
\text { from time to time according to some } \\
\text { religious prompting. It is a very subjec- } \\
\text { tive article, and the symbolism seems to } \\
\text { be somewhat individual. Several other } \\
\text { like specimens, which unfortunately could } \\
\text { not be obtained, were partly explained }\end{array}$ \\
\hline & I NDIAN NOTES \\
\hline
\end{tabular}




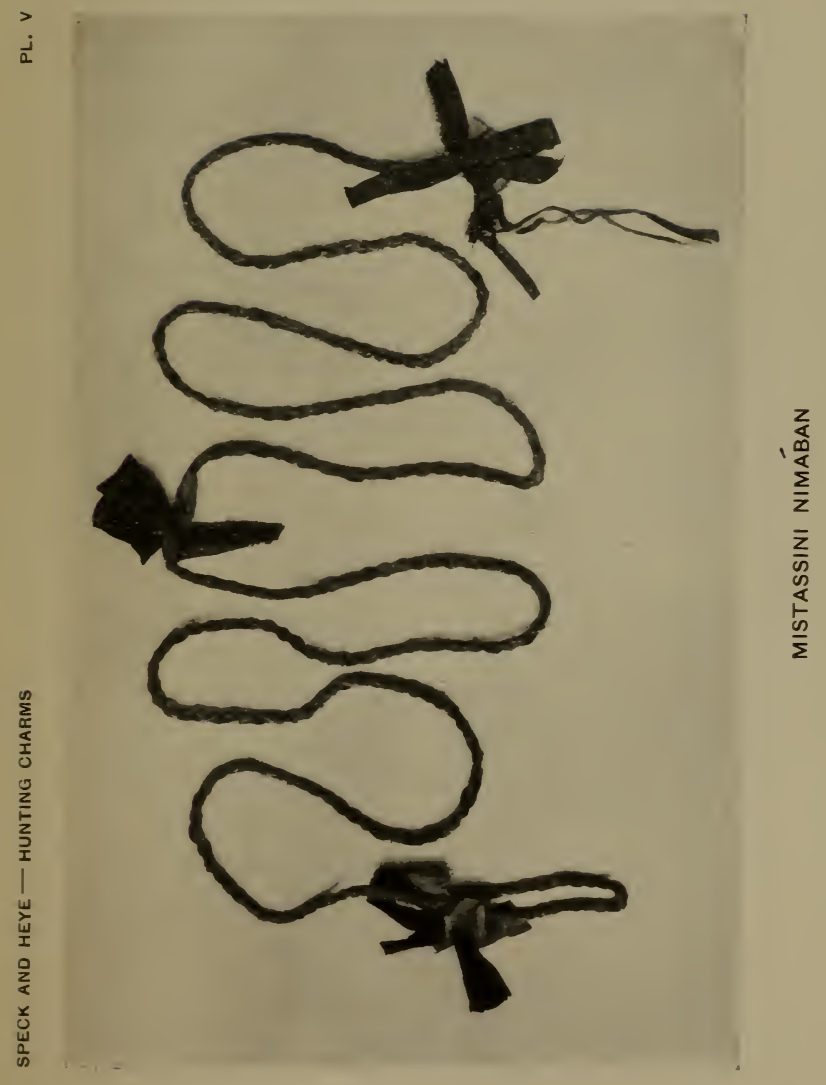





\begin{tabular}{|l|l|}
\hline H U N T I N G C H A R M S & \\
\hline by the Mistassini, but complete infor- \\
mation regarding them was not available, \\
as the hunters do not betray their secrets \\
even to one another. The occasion for \\
doing so seldom arises, as each man is his \\
own ceremonial official and practises his \\
rites when he is alone. Individualism of a \\
generally similar type will be found to be \\
the keynote to the ceremonialism of all \\
the Algonkians of the eastern Canadian \\
and Hudsonian zones.
\end{tabular}




SMITHSONIAN INSTITUTION LIBRARIES |||||||||||||||| |||||||||||||||||||||||||||| ||||||||||||||| |||||||||||||||| 